\title{
The Evaluation of a General Purpose Bale System Performance and Its Bale Quality
}

\author{
Dongil Chang ${ }^{1}$, Sun-ok Chung ${ }^{1}$, Byoung-kwan Cho', Dongseok Park ${ }^{1}$, Namseok Sung ${ }^{1}$, \\ Jungchul Kim', Inhyun Lee ${ }^{2}$, Jutaek Park ${ }^{2}$ \\ ${ }^{1}$ Department of Biosystems Machinery Engineering, Chungnam National University, Daejeon, Korea \\ ${ }^{2}$ Research Center, Myungsung Co., Ltd., Doil-dong, Pyeongtaek-si, Gyeonggi-do, Korea
}

Received: August $8^{\text {th }}, 2013$; Revised: November $11^{\text {th }}, 2013$; Accepted: November $26^{\text {th }}, 2013$

\section{Abstract}

Purpose: The objectives of this study were to develop a general purpose baler system that is appropriate for the domestic forage cultivation environment and operated by the medium size tractor for production of bale silage made of green forage crops, and to test its performance. Methods: In a first experiment, the time of formation per one bale and densities of bales that are produced from bale system, were measured. In a second experiment, power requirement was measured by a power measurement system manufactured during bale system work. Results: The power measurement system was constructed with strain-gage sensors to measure torque of a PTO axle and proximity sensor to measure rotating speed of a PTO axle. Thus, the power requirement was calculated by PTO torque and PTO rotating speed. For evaluation of bale quality, the samples of bales were analyzed for contents of moisture, ADF, NDF and TDN. Conclusions: If the results of this study will be utilized, the coefficient of utilization of agricultural machinery will be increased by the operation of a medium size tractor that is a major disseminated tractor in farm, and it will contribute tremendously to make a forage production base for livestock farms.

Keywords: Bale quality, Bale system, Performance, Power requirement, PTO

\section{Introduction}

In Korean livestock industry, the cost of feed comprises more than half of management costs. Therefore, the necessity of supplying energy source that is essential to grass-eating animal has been increasing. But it can be achieved by cultivation and utilization of winter forage crops such as green barley, Italian ryegrass, rye, using paddy fields or idle farm land, and it is a way to escape from the excessive concentrated fodder feeding.

Song et al. (2009) investigated the effects of cutting heights of forage crops on productivity and quality of forage. In their study, they harvested green barley, rye, triticale, and forage wheat with baler cutting height of 5

\footnotetext{
*Comesponding author: Dongil Chang

Tel: +82-42-821-6718; Fax: +82-42-823-6246

E-mail: dichang@cnu.ac.kr
}

$\mathrm{cm}, 10 \mathrm{~cm}$, and $20 \mathrm{~cm}$. And they analyzed and reported the production quantity, quality and economics of forage crops according to the baler cutting heights. Kim et al. (2011) analyzed power requirement of an agricultural tractor for baler operation. They developed a power measurement system and installed in a $75 \mathrm{~kW}$ agricultural tractor, and concluded that the power requirement of tractor was affected by the PTO rotational speed for baler operation. An energy saving model was selected by Freeland and Bledsoe (1988) for the fixed-geometry chamber type and variable-geometry chamber type baler. According to their work, energy required to form large round hay bales was affected by the operational procedure and baler chamber type. Rummer et al. (2011) evaluated two round baling systems (bio-baler and general baler) for harvesting understory biomass and reported productivity and quality of baler, and fuel consumption rate for baling systems. 
Recently, since Korean government is pushing ahead with the policy of self-sufficiency forage production, and for the importance of it, farmers awareness are being enhanced, forage production area and its self-sufficiency ratio are getting increased every year. For supplying the economical and good quality forage all the year round, the following systems should be prepared, such as vitalization of winter and summer forage crops cultivation, preparation of large quantity production base for the harvesting and processing system of silage, and labor reduction systems.

Therefore, the objectives of this study were to develop a general purpose baler system that is appropriate for the domestic forage cultivation environment and operated by the medium size tractor for production of bale silage made of green forage crops, and to test its performance.

\section{Materials and Methods}

\section{Tractor}

In order to test the performance of baler developed, a medium size tractor was used for the baler operation as a

\section{Table 1. Specification of tractor used in study}

\begin{tabular}{|c|c|c|}
\hline \multicolumn{2}{|c|}{ Item } & Specification \\
\hline \multicolumn{2}{|c|}{ Engine } & $47 \mathrm{~kW} / 2,500 \mathrm{rpm}$ \\
\hline \multirow{3}{*}{ Size (mm) } & Length & 3,600 \\
\hline & Width & 1,820 \\
\hline & Height & 2,460 \\
\hline \multicolumn{2}{|c|}{ Weight(kg) } & 2,545 \\
\hline \multicolumn{2}{|c|}{ PTO(rpm) } & $564 / 795 / 1,125$ \\
\hline
\end{tabular}

source of power to baler. Its size was 3,600 (L) $\times 1,820$ $(\mathrm{W}) \times 2,460(\mathrm{H}) \mathrm{mm}$ as shown in Table 1 . Its weight was $2,545 \mathrm{~kg}$, and its engine power was $47 \mathrm{~kW}$ for 2,500 rpm.

\section{Bale system}

In the study, a bale system (Figure 1) was designed and manufactured that could produce a round bale of $1.0 \mathrm{~m}$ diameter and $1.0 \mathrm{~m}$ width. This round bale system has 1.6 $m$ pickup width and consists of cutting and transfer unit, pressure device and bale formation unit, and binding and discharging unit. The function of the cutting and transfer unit is cutting the forage crops using chopper and transferring the chopped forage crops to bale formation unit.

By the preliminary test, it was found that tractor tires trod on forage crops, and as a results of this, the chopper of bale system could not cutting the crops and those trod crops were lost. Therefore, the bale system used in the test was not connected with the tractor in a straight line. Rather it was connected with a partial disposition of $1,000 \mathrm{~mm}$ right side of tractor, in order not to tread on forage crops.

\section{Measurement of PTO power requirement}

A torque meter was designed and made for measuring the power requirement of PTO during the test of bale system operation, as shown in Figure 2.

The torque meter was made of four strain gages (KFG2-120-C1-11, Kyowa, Japan) to measure torque, slip ring(Younghwa ENG, Korea) to transfer electronic signal from strain gage, and proximity sensor to measure the rotation speed of PTO. These sensors were attached to a universal joint. Power requirement of baler for a bale
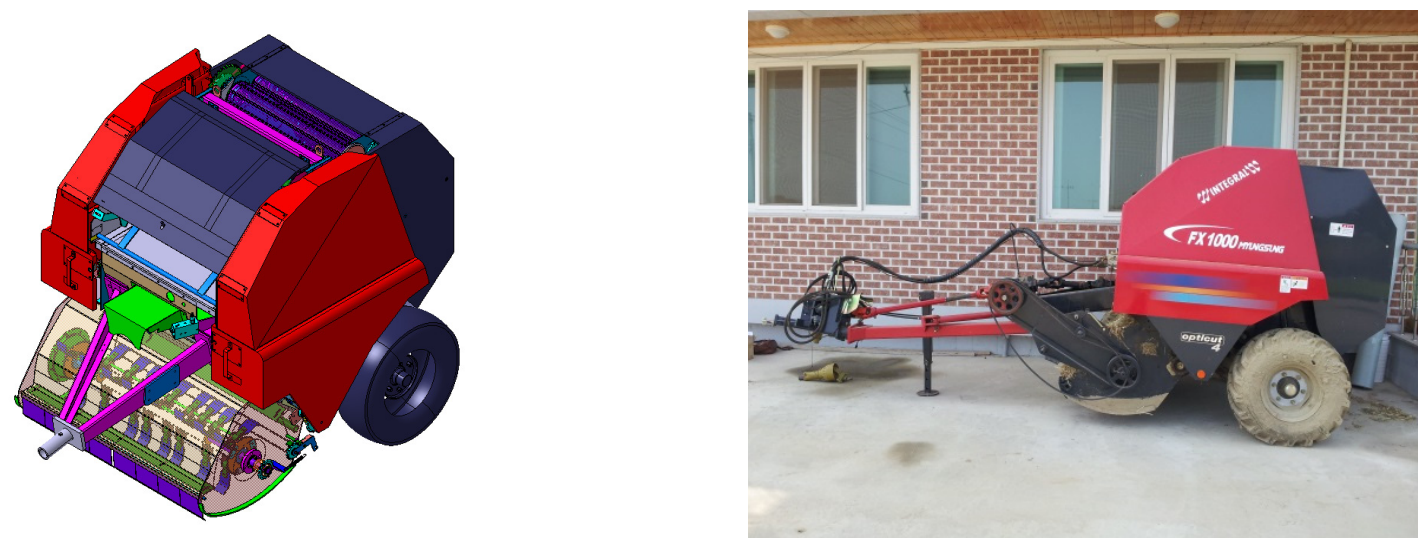

Figure 1. Bale system used in study. 


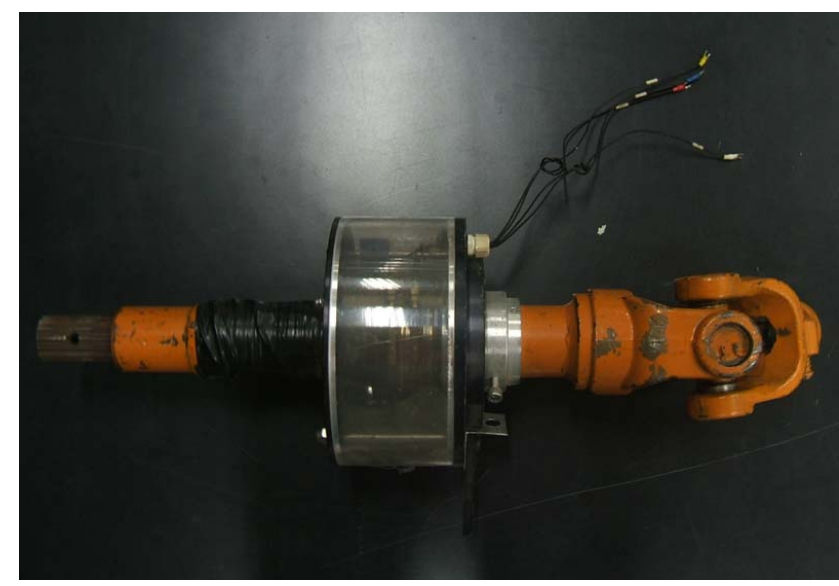

Figure 2. Picture of the torque meter used in the test.

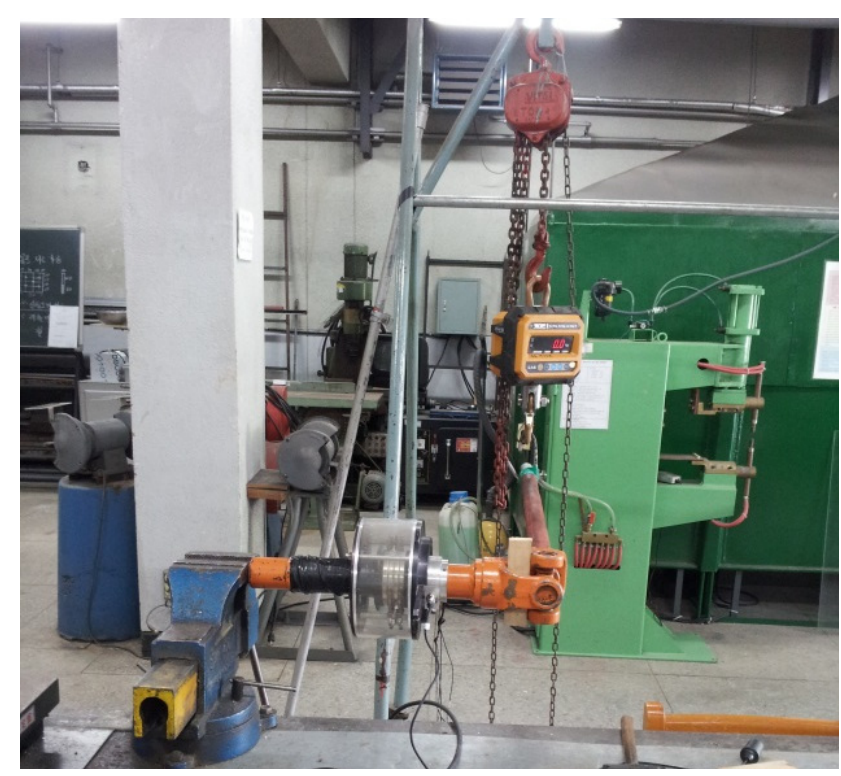

Figure 3. Calibration test of the torque meter.

formation cycle was calculated by Equation (1).

$$
P_{a x l e}=\frac{2 \pi \times T \times N}{60,000}
$$

where, $\mathrm{P}=$ Required power, $\mathrm{kW}$

$$
\begin{aligned}
\mathrm{T} & =\text { Torque, } \mathrm{Nm} \\
\mathrm{N} & =\text { Rotational speed, } \mathrm{rpm}
\end{aligned}
$$

Strain gages consist of a Wheatstone bridge by sticking four gages at equal intervals and were mounted at angle of 45 degrees to axis direction of universal joint. After amplification of strain gage signal by passing the bridge box and amplifier, the signal was recorded in computer through A/D convertor.

\section{Calibration test of torque meter}

For calibration test, the universal joint was fixed horizontally as shown in Figure 3. The end of torque arm was connected to universal joint and the opposite was connected to load cell. The output signal was tested by a multimeter and recorded whenever the force was applied to torque arm.

\section{Performance test of bale system}

The performance test of bale system was carried out with green barley in Buyeo-gun, Chungchungnam-do Province.

\begin{tabular}{|c|c|c|c|}
\hline \multicolumn{3}{|c|}{ Cone index $(\mathrm{kPa})(\mathrm{n}=25)$} & \multirow{2}{*}{$\begin{array}{l}\text { Water content } \\
\qquad(\%)(n=10)\end{array}$} \\
\hline $5 \mathrm{~cm}$ & $10 \mathrm{~cm}$ & $15 \mathrm{~cm}$ & \\
\hline $483.7 \pm 223.9$ & $868.2 \pm 489.2$ & $1983.2 \pm 705.3$ & $6.86 \pm 1.53$ \\
\hline
\end{tabular}
The properties of soil of the test field are shown in Table 2. For the test, tractor was operated with $6.6 \mathrm{~km} / \mathrm{h}$
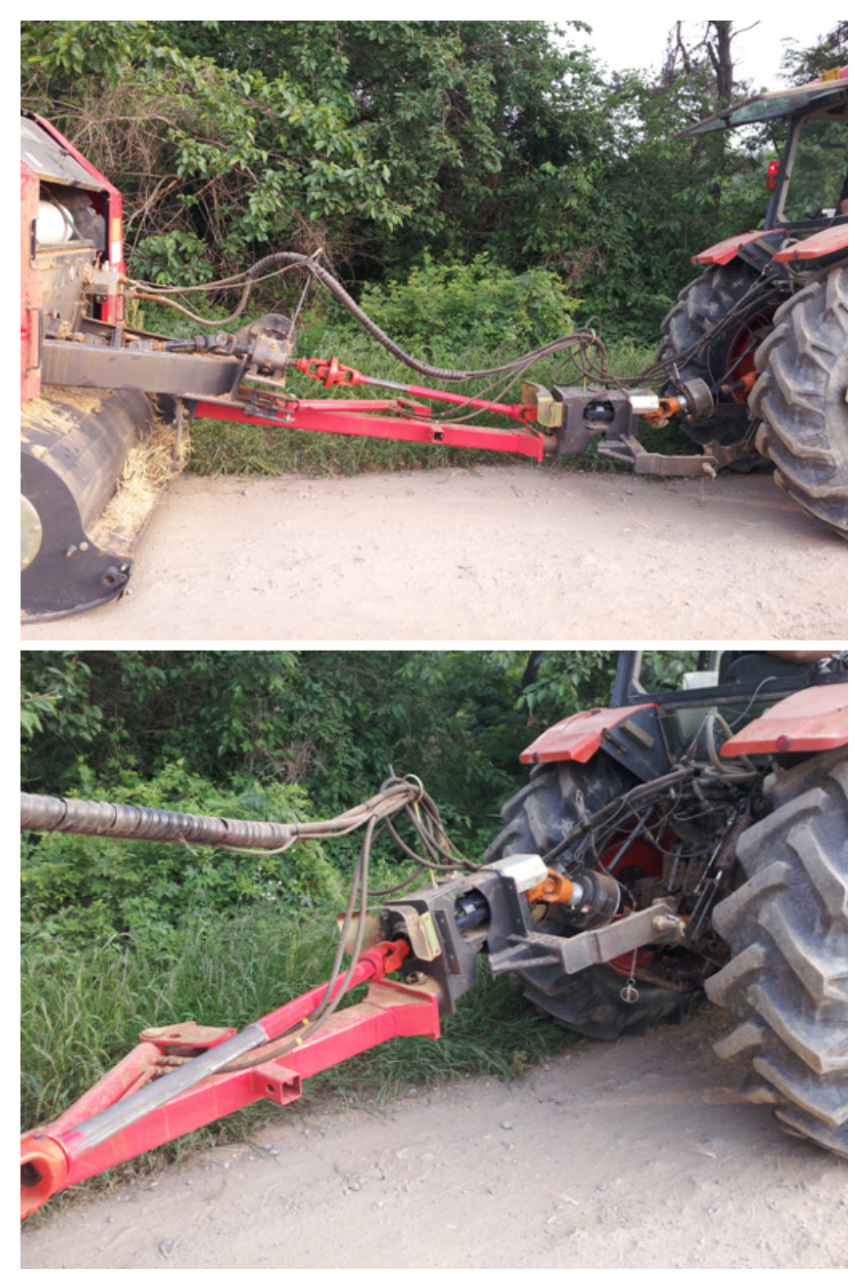

Figure 4. Connection of PTO power measurement. 
velocity and PTO rotational speed of $564 \mathrm{rpm}$. During the test, the bale system was controlled to stop bale formation and discharge the finished bale when the pressure of bale chamber reached 100 bar.

In order to evaluate the bale system performance, the travel distance of baler was measured by a measuring tape and time was measured by a stop watch, for formation and discharging one roll of finished bale of green barley. For measuring the required power of bale operation of the baler tested, tractor and bale system was connected with the power measuring system as shown in Figure 4.

In order to evaluate the physical properties of bale, when the bale operation was finished, five rolls of bale were sampled randomly and their size, weight, and density were measured. For the nutrition evaluation of green barley forage, three rolls of bale were sampled randomly and $200 \mathrm{~g}$ of sample was taken from each roll. Then those samples were officially analyzed for contents of moisture, ADF (Acid Detergent Fiber), NDF (Neutral Detergent Fiber) by National Academy of Agricultural Science. TDN (Total Digestible Nutrients) was calculated by the Equation (2), based on the theory that TDN has a high correlation with the dry matter digestibility and amount of intake of ADF. All experiment procedures were performed on the basis of Test Method of Agricultural Baler at National Academy of Agricultural Science (NAAS, 2011).

$$
\operatorname{TDN}(\%)=88.9-(0.79 \times \mathrm{ADF}(\%))
$$

\section{Results and Discussion}

The calibration results of torque meter showed high accuracy such as 0.99 of $\mathrm{R}^{2}$ for the measured range of 0 500 Nm as shown in Figure 5.

The average travelling distance of bale system was 139 $\mathrm{m}$ for a finished roll of bale. For a bale formation, 123 seconds was taken and 5 seconds for bale discharge, 128 seconds totally, on average. The results of measurement of size and weight of five finished rolls of bale sampled randomly were shown as Table 3 on average such as 1.1 $\mathrm{m}$ diameter, $0.95 \mathrm{~m}$ width, and $424 \mathrm{~kg}$ weight, and 470.53 $\mathrm{kg} / \mathrm{m}^{3}$ density.

The following Figure 6 showed the results of the power requirements of bale system tested for bale operation. The amount of power requirement had been increasing during forage harvesting and bale formation, and it

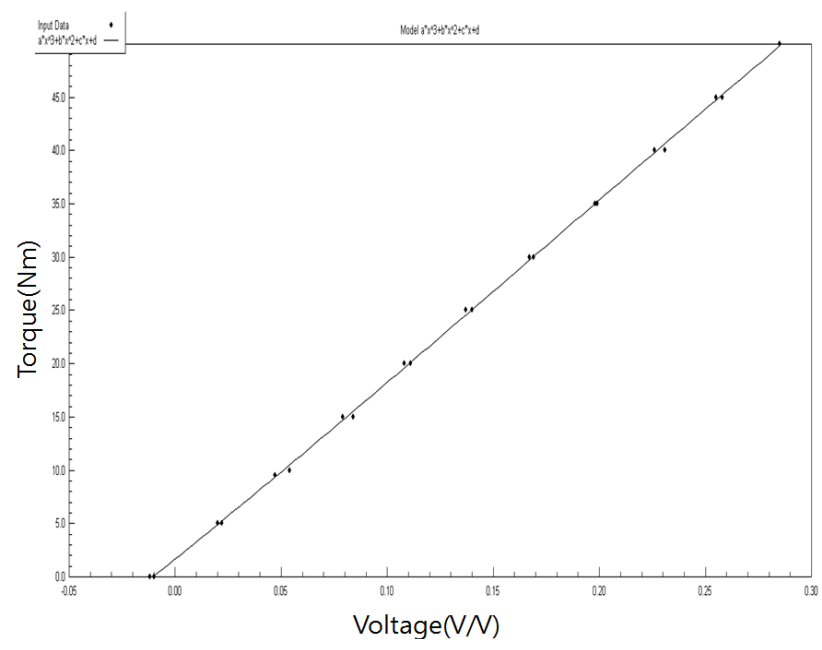

Figure 5. Calibration curve of torque meter.

Table 3. Specifications of the finished bale $(n=5)$

\begin{tabular}{|c|c|c|c|c|}
\hline \multicolumn{3}{|c|}{ Size } & \multirow[b]{2}{*}{ Weight (kg) } & \multirow{2}{*}{$\begin{array}{l}\text { Density } \\
\left(\mathrm{kg} / \mathrm{m}^{3}\right)\end{array}$} \\
\hline $\begin{array}{l}\text { Diameter } \\
(\mathrm{m})\end{array}$ & Width (m) & Volume $\left(\mathrm{m}^{3}\right)$ & & \\
\hline $1.10 \pm 0.02$ & $0.95 \pm 0.02$ & $0.90 \pm 0.03$ & $424.00 \pm 9.37$ & $70.53 \pm 18.59$ \\
\hline
\end{tabular}

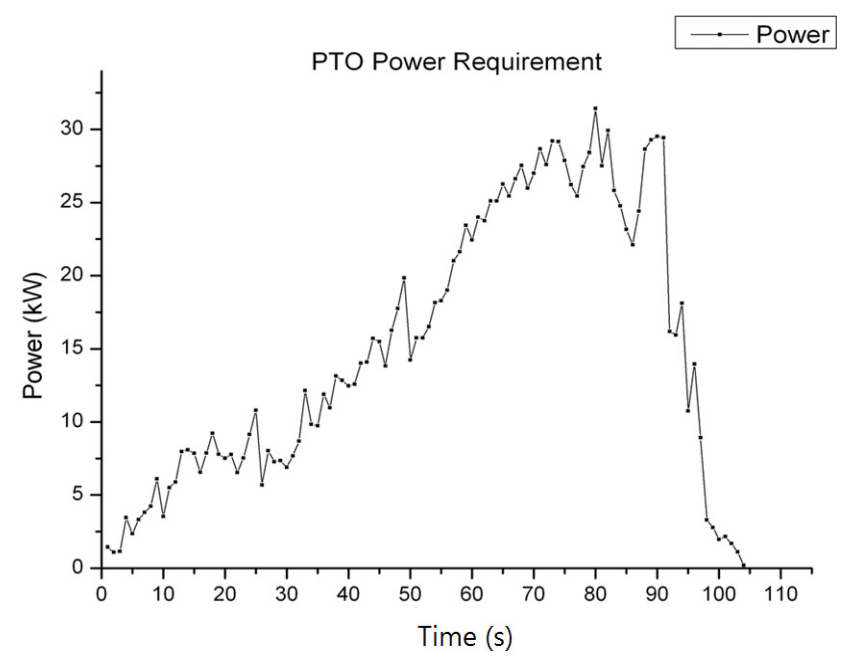

Figure 6. Power requirements of the bale system tested.

reached the maximum just before the discharge of finished bale. After bale formation, when bale operation was stopped and discharged the finished bale, the amount of power requirement was suddenly decreased as the Figure 6. As a result, average power requirement was $15.1 \mathrm{~kW}$, and the maximum was $31.4 \mathrm{~kW}$. The analyzed results of bale samples made of green barley showed that $66.3 \%$ moisture content, $10.7 \% \mathrm{ADF}, 20.7 \% \mathrm{NDF}$, and $80.5 \%$ TDN. 


\section{Conclusions}

The objectives of this study were to develop a general purpose baler system operated by the medium size tractor for production of bale silage made of green forage crops, and to test its performance. In order to test the baler developed, time and required power were measured for production of a bale. Then its quality was evaluated. According to the test results, the tested bale system traveled $139 \mathrm{~m}$ averagely, and worked for 128 seconds for rolling and discharge of one roll of bale. During the operation of the bale system, the average power requirement was $15.1 \mathrm{~kW}$ and the maximum one was $31.4 \mathrm{~kW}$. The density of the finished bale was $470.53 \mathrm{~kg} / \mathrm{m}^{3}$, and the content of TDN was $80.5 \%$. If the results of this study will be utilized, the coefficient of utilization of agricultural machinery will be increased by the operation of a medium size tractor that is a major disseminated tractor in farm, and it will contribute tremendously to make a forage production base for livestock farms.

\section{Conflict of Interest}

The authors have no conflicting financial or other interests.

\section{Acknowledgement}

This work was carried out with the support of "Cooperative Research Program for Agriculture Science \& Technology Development (Project No. PJ0076782012)" Rural Development Administration, Republic of Korea.

\section{References}

Freeland, R. S and B. L. Bledsoe. 1988. Energy required to form large round hay bales-effect of operational procedure and baler chamber type. TRANSACTIONS of the ASAE 31(1):63-67.

Jenkins B. M., D. Toenjes, J. B. Dobie and J. F. Arthur. 1985. Performance of large balers for collecting rice straw. TRANSACTIONS of the ASAE 28(2):360-363.

Kim, Y. J., D. H. Lee, S. O. Chung, S. J. Park and C. H. Choi. 2011. Analysis of power requirement of agricultural tractor during baler operation. Journal of Biosystems Engineering 36(4):243-251.

NAAS. 2011. Test Method of Agricultural Baler. South Korea.: National Academy of Agricultural Science. Available at: www.naas.go.kr. Accessed 5 October 2011.

Rummer, B., J. L. D. Canto, J. Klepac, P. Savoie and F. Seixas. 2011. Evaluation of two round baling systems for harvesting understory biomass. Biomass and Bioenergy, 35(2011):2163-2170.

Song, T. H., O. K. Han, T. I. Park, J. H. Seo, S. K. Yun and K. H. Park. 2009. Effects of cutting height on productivity, feed value and economical efficiency of winter cereal crops for forage. The Journal of the Korean Society of International Agriculture 21(4):322-326. 